\title{
Transport of maltose in Saccharomyces cerevisiae
}

\author{
Effect of $\mathrm{pH}$ and potassium ions
}

\author{
Maria C. LOUREIRO-DIAS* and José M. PEINADO† \\ *Laboratory of Microbiology, Gulbenkian Institute of Science, Oeiras, Portugal, and \\ $\dagger$ Departamento de Microbiología, Facultad de Ciencias, Badajoz, Spain
}

(Received 3 January 1984/Accepted 8 May 1984)

\begin{abstract}
The transport of maltose in Saccharomyces cerevisiae has been generally accepted as a $\mathrm{H}^{+}$-sugar symport, with a stoichiometrical ratio of $1: 1$. A simultaneous exit of $\mathrm{K}^{+}$ from the cells with the initial uptake of maltose has been reported previously. By using $\mathrm{a} \mathrm{K}^{+}$-selective electrode and radioactive maltose, we were able to measure the exit of $1 \mathrm{~mol}$ of $\mathrm{K}^{+} / \mathrm{mol}$ of maltose taken up by the cells in the first $10-15 \mathrm{~s}$. This stoichiometrical ratio is $\mathrm{pH}$-independent. So, uptake of protons in a non-buffered cell suspension or exit of $\mathrm{K}^{+}$in a buffered one can be used to measure initial rates of maltose uptake. We have used a $\mathrm{K}^{+}$electrode and a pH electrode to study the effect of external $\mathrm{pH}$ and $\mathrm{K}^{+}$respectively on the kinetic parameters of maltose transport. The following results were obtained: the apparent half-saturation constant for maltose $\left(K_{\mathrm{m}}\right)$ increased from $5.2 \mathrm{mM}$ at $\mathrm{pH} 5.8$ to $38.0 \mathrm{mM}$ at $\mathrm{pH} 7.8$; the same increase in $\mathrm{pH}$ halved the apparent maximum uptake rate $\left(V_{\text {max. }}\right) ; \mathrm{K}^{+}$had an inhibitory effect, decreasing $V_{\text {max. }}$ and increasing $K_{\mathrm{m}}$ at $\mathrm{pH}$ values above $5 ; \mathrm{K}^{+}$had a stimulating effect at $\mathrm{pH}$ values below or equal to 4 . Under physiological conditions, i.e. lower $\mathrm{pH}$ outside, neutral $\mathrm{pH}$ inside and much higher $\left[\mathrm{K}^{+}\right]$inside the cell, and assuming symmetry of the system, a higher affinity for maltose is to be expected in the outer face of the plasma membrane. This behaviour of the system could explain, by itself, the maintenance of the high concentration of free maltose inside the cell (necessary because of the low affinity of the maltase), without significant back transport to the outside.
\end{abstract}

The maltose permease of Saccharomyces cerevisiae has been described as a proton symport. Seaston et al. (1973) showed that maltose was absorbed with protons by a mechanism that did not involve ATP directly, since it was functional in the presence of 2-deoxyglucose, antimycin and iodoacetamide.

The stoichiometrical ratio was established as about $1 \mathrm{~mol}$ of protons/mol of maltose (Eddy et al., 1977; Serrano, 1977).

The inhibitory effect of protonophores studied by Serrano (1977) was interpreted as a proof for the electrogenic character of the transport system, which would use the electrochemical proton gradient across the plasma membrane as a source of energy.

The electrogenic character of the transport system was also studied by changes in fluorescence signals of carbocyanine dyes (Brocklehurst et al.,
1977); these results are not considered to be conclusive (Eddy, 1982), because of interference with mitochondrial events.

$\mathrm{K}^{+}$is released by the yeast cells during the initial uptake of maltose. This was interpreted as a mechanism to maintain electrical balance, during the influx of protons, together with maltose, before the proton pump is activated (Serrano, 1977). The same efflux of $\mathrm{K}^{+}$was observed in the presence of proton conductors (Seaston et al., 1976), with a stoichiometrical ratio of about $1 \mathrm{~mol}$ of $\mathrm{K}^{+}$ released $/ \mathrm{mol}$ of $\mathrm{H}^{+}$taken up.

External pH has been shown to affect the specific rate of growth of a petite mutant of $S$. cerevisiae on maltose in the $\mathrm{pH}$ range 5-7, whereas it had no effect when the cells were growing on glucose or galactose (Olivero et al., 1982). The specific growth rate $(\mu)$ depends on the growth yield $(y)$ and the specific transfer rate of a nutrient 
(k), according to the equation (van Uden, 1969):

$$
\mu=k \cdot y
$$

Data from continuous and batch culture suggested that the effect of $\mathrm{pH}$ on the specific growth rate might be related to the transport step, since no effect was detected on the growth yield.

In the present work we used measurements with a $\mathrm{K}^{+}$-selective electrode to study the effect of external $\mathrm{pH}$ and measurements with a $\mathrm{pH}$ electrode to study the effect of $\mathrm{K}^{+}$on the kinetic parameters of maltose transport of $S$. cerevisiae.

\section{Experimental}

\section{Organism, growth and harvesting conditions}

Saccharomyces cerevisiae (I.G.C. 3507) was grown on a mineral medium (van Uden, 1967) containing $2 \%(\mathrm{w} / \mathrm{v})$ maltose, in an orbital shaker, at $25^{\circ} \mathrm{C}$. Exponential-phase cells (about $1 \mathrm{mg}$ dry wt./ml of medium) were harvested by centrifugation, washed twice with water at $4^{\circ} \mathrm{C}$ and resuspended in water to a final concentration of about $100 \mathrm{mg}$ dry wt. $/ \mathrm{ml}$. These cells were kept in ice for $1 \mathrm{~h}$ before any experiment and were used during the next $4 \mathrm{~h}$. The biomass in each batch of cells was determined by weighing the cells in $100 \mu \mathrm{l}$ of suspension, after drying overnight at $80^{\circ} \mathrm{C}$.

\section{Measurement of maltose transport by the uptake of $\left[{ }^{14} \mathrm{C}\right]$ maltose}

We used the method described by Serrano (1977). A $20 \mu \mathrm{l}$ volume of buffer $(0.1 \mathrm{M}$-Tris adjusted to the desired $\mathrm{pH}$ with tartaric acid) was mixed with $20 \mu \mathrm{l}$ of cell suspension. After $5 \mathrm{~min}$ incubation at $26^{\circ} \mathrm{C}, 10 \mu \mathrm{l}$ of [U-14 C]maltose (about 100 c.p.m./nmol) was added; transport was stopped by the addition of $5 \mathrm{ml}$ of ice-cold water after $5,10,15$ and $20 \mathrm{~s}$. The suspension was immediately filtered through Whatman $2.5 \mathrm{GF} / \mathrm{C}$ glass-microfibre filters, washed on the filter with $5 \mathrm{ml}$ of ice-cold water and the radioactivity counted in a Beckman LS 8100 liquid-scintillation system.

Controls were performed by adding $5 \mathrm{ml}$ of cold water to the cells before the addition of radioactive solutions and proceeding as before.

[U-14 C]Maltose was purchased from The Radiochemical Centre, Amersham, Bucks., U.K. Maltose was grade I from Sigma Chemical Co., St. Louis, MO, U.S.A.

\section{Measurement of proton uptake}

Proton uptake was measured with a combined pH electrode (G-202 B; Radiometer) attached to a standard pH-meter (PHM 62; Radiometer) connected to a flat-bed potentiometer recorder $(6500$; LKB). The pH electrode was inmersed in a waterjacketed cell with magnetic stirring. First, $3.5 \mathrm{ml}$ of water and $0.5 \mathrm{ml}$ of cell suspension were successively added and a base-line was obtained in the recorder, after adjustment to the required $\mathrm{pH}$ with $\mathrm{HCl}$. The addition of maltose solutions switched on the uptake of protons, observed through the alkalinization of the extracellular environment. From the slope of the initial part of the curve obtained in the recorder, initial rates of proton uptake were calculated. Calibrations were made with $10 \mathrm{~mm}-\mathrm{HCl}$. All assays were performed at $26^{\circ} \mathrm{C}$.

\section{Measurement of $\mathrm{K}^{+}$efflux}

$\mathrm{K}^{+}$efflux was measured with a $\mathrm{K}^{+}$-selective electrode (F 2312 electrode; Radiometer), with as reference a double-bridge calomel electrode (R11; Philips), immersed in a conical water-jacketed cell with magnetic stirring. The electrodes were attached to the same equipment as the $\mathrm{pH}$ electrode in the proton-uptake measurements. To $3.5 \mathrm{ml}$ of buffer $(0.1 \mathrm{M}$-Tris adjusted to the desired $\mathrm{pH}$ with tartaric acid), $0.5 \mathrm{ml}$ of cell suspension was added. A base-line was obtained, and the addition of maltose switched on the efflux of $\mathrm{K}^{+}$. From the slope of the initial part of the curve obtained in the recorder, initial rates of $\mathrm{K}^{+}$efflux were calculated. Calibrations were made with $1 \mathrm{mM}-\mathrm{KCl}$. All assays were performed at $26^{\circ} \mathrm{C}$.

In the experiments for determining the maltose/ $\mathrm{K}^{+}$stoichiometrical ratio, the relative proportions of buffer and cell suspension were the same as in the $\left[{ }^{14} \mathrm{C}\right]$ maltose-uptake assays, for a final volume of $4 \mathrm{ml}$.

\section{Results}

Figs. $1(a)$ and $1(b)$ illustrate typical curves obtained with $\mathrm{pH}$ and $\mathrm{K}^{+}$electrodes respectively. $\mathrm{H}^{+}$influx and $\mathrm{K}^{+}$efflux occurred simultaneously and immediately after the addition of the maltose pulse; we could not detect any time delay with the equipment with which we were working.

To study the effect of $\mathrm{pH}$ on the transport of maltose, the measurement of $\mathrm{K}^{+}$efflux would be a useful tool, but first we need to calculate the maltose $/ \mathrm{K}^{+}$stoichiometrical ratio. We measured uptake of $\left[{ }^{14} \mathrm{C}\right]$ maltose and $\mathrm{K}^{+}$efflux at different $\mathrm{pH}$ values and maltose concentrations to cover a range of uptake rates from the highest that we could get to the lowest that we could measure. Fig. 2 summarizes the results. The stoichiometrical ratio obtained from the slope of the regression line was $1.03 \mathrm{~mol}$ of $\mathrm{K}^{+}$released $/ \mathrm{mol}$ of maltose uptaken.

The measurements of $\mathrm{K}^{+}$efflux could therefore be used as a measure of maltose transport, and we used the $\mathrm{K}^{+}$electrode to study the effect of external $\mathrm{pH}$. 
(a)

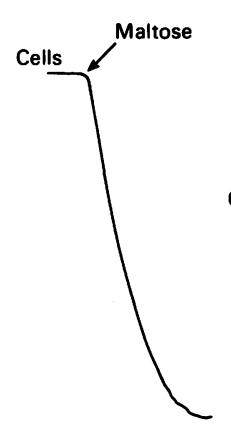

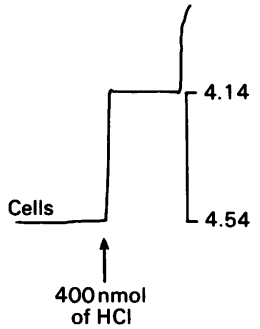

$20 \mathrm{~s}$

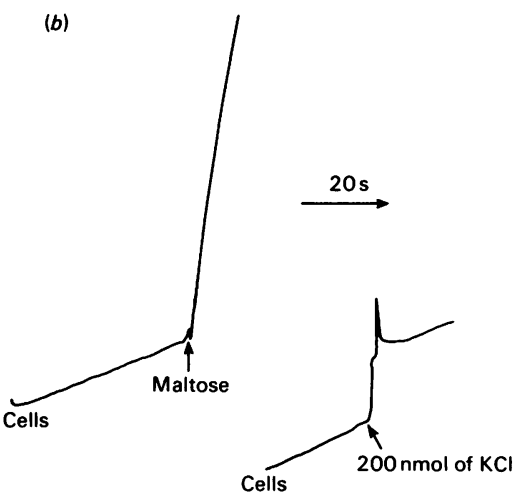

Fig. 1. Alkalinization (a) and increase in the extracellular $K^{+}$concentration $(b)$ of a cell suspension of $S$. cerevisiae grown on maltose, after the addition of a pulse of maltose

The slope of the initial part of the curves was used to measure the initial rate of $\mathrm{H}^{+}$uptake $(a)$ or $\mathrm{K}^{+}$efflux (b). To $4 \mathrm{ml}$ of cell suspension, $100 \mu \mathrm{l}$ of $2 \mathrm{M}$-maltose was added.

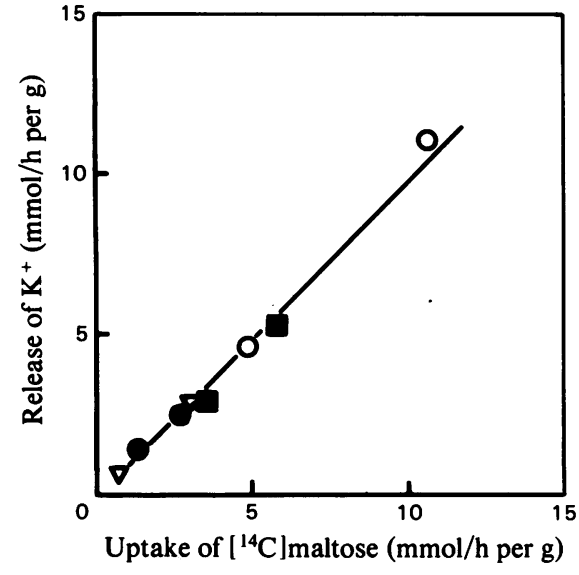

Fig. 2. Stoichiometry of initial maltose uptake and $\mathrm{K}^{+}$ efflux in S. cerevisiae

Initial maltose uptake was measured by the incorporation of $\left[{ }^{14} \mathrm{C}\right]$ maltose, and $\mathrm{K}^{+}$efflux was measured with a selective electrode. Cells were suspended in $100 \mathrm{mM}$-Tris adjusted with tartaric acid to $\mathrm{pH} 3.76(0), \mathrm{pH} 4.73(\mathrm{O}), \mathrm{pH} 5.88(\square)$ and pH $7.16(\nabla)$.

\section{Effect of $\mathrm{pH}$}

We measured the effect of $\mathrm{pH}$ on the efflux of $\mathrm{K}^{+}$after the addition of a pulse of maltose (final concentration $50 \mathrm{~mm}$ ) in the $\mathrm{pH}$ range $2.7-8.5$. There was a maximum in the range $4.5-6.0$ with a strong decrease for $\mathrm{pH}$ below 4 and above 7 . On varying the $\mathrm{pH}$ and the maltose concentration, the efflux of $\mathrm{K}^{+}$showed the kinetic pattern presented in Fig. 3, by Eadie-Hofstee plots. External pH affected both the apparent half-saturation constant $\left(K_{\mathrm{m}}\right)$ and the apparent maximum uptake rate

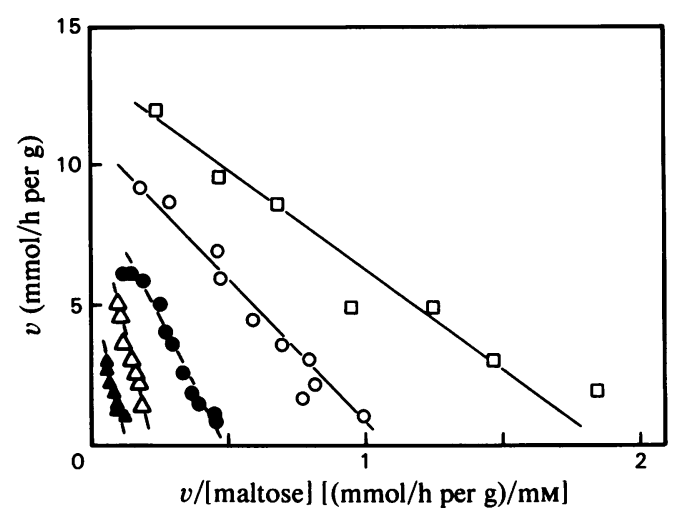

Fig. 3. Effect of external $\mathrm{pH}$ on the kinetic parameters of the maltose-transport system of $S$. cerevisiae The initial rates of maltose uptake were measured as $\mathrm{K}^{+}$efflux with a $\mathrm{K}^{+}$-selective electrode. The cells were suspended in $100 \mathrm{~mm}$-Tris adjusted with tartaric acid to pH $5.97(\square), \mathrm{pH} 6.45(\mathrm{O}), \mathrm{pH} 6.90$ $(\mathrm{O})$, pH $7.34(\triangle)$ and $\mathrm{pH} 7.75(\Delta)$

$\left(V_{\text {max. }}\right)$, and a summary of the values obtained is shown in Table 1.

The low rates obtained for low $\mathrm{pH}$ (confirmed with the uptake of $\left[{ }^{14} \mathrm{C}\right]$ maltose; see Fig. 2) were not in agreement with the previous knowledge that the strain of $S$. cerevisiae used maltose at $\mathrm{pH}$ values below 3. We evaluated kinetic parameters in the range of low pH (below 4) and observed that $K_{\mathrm{m}}$ did not vary (about $5 \mathrm{~mm}$ ) but that $V_{\text {max. }}$ was much lower (results not shown).

\section{Effect of $\mathrm{K}^{+}$}

To study the effect of $\mathrm{K}^{+}$on the transport of maltose, we measured the uptake of protons as 
Table 1. Effect of external pH on the kinetic parameters of the maltose-transport system of $S$. cerevisiae Values were calculated from the Eadie-Hofstee plots of Fig. 3.

$\begin{array}{ccc}\text { pH } & \begin{array}{c}V_{\text {max. }} \\ (\mathrm{mmol} / \mathrm{h} \text { per } \mathrm{g})\end{array} & \begin{array}{c}K_{\mathrm{m}} \\ (\mathrm{mM})\end{array} \\ 7.75 & 5.32 & 38.0 \\ 7.34 & 8.12 & 33.2 \\ 6.90 & 9.18 & 19.3 \\ 6.45 & 9.67 & 8.7 \\ 5.79 & 11.14 & 5.2\end{array}$

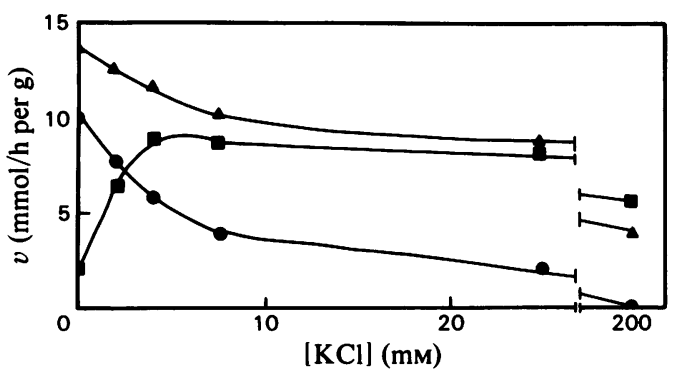

Fig. 4. Effect of $\mathrm{K}^{+}$on the maltose-transport system of $S$. cerevisiae

The initial rates of maltose uptake were measured as $\mathrm{H}^{+}$uptake with a pH electrode. Maltose was added to a final concentration of $50 \mathrm{mM} ; \Delta, \mathrm{pH} 4.7 ; \square$, $\mathrm{pH} 4.0 ; 0, \mathrm{pH} 6.0$

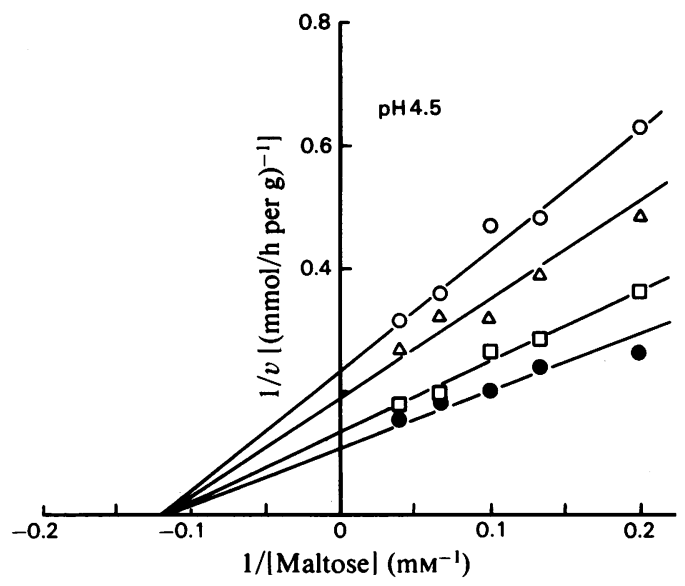

Fig. 5. Effect of $\mathrm{K}^{+}$on the kinetic parameters of the maltose-transport system of $\mathrm{S}$. cerevisiae at pH4.5 The initial rates of maltose uptake were measured as $\mathrm{H}^{+}$uptake with a $\mathrm{pH}$ electrode. $\mathrm{KCl}$ was added to the cell suspension to a final concentration of $10 \mathrm{mM}$ $(\square), 50 \mathrm{~mm}(\triangle)$ and $150 \mathrm{~mm}(O)$. Control is represented by

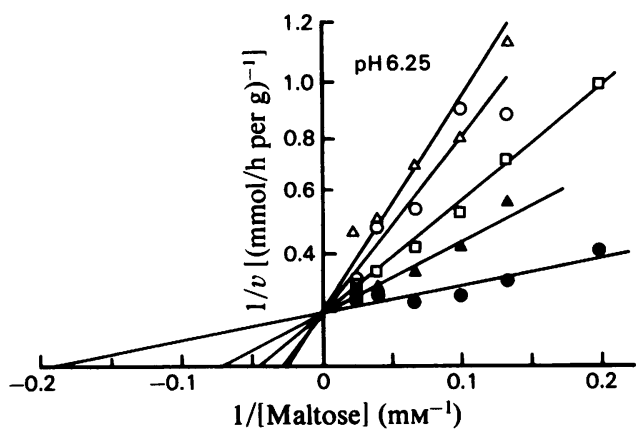

Fig. 6. Effect of $\mathrm{K}^{+}$on the kinetic parameters of the maltose-transport system of $S$. cerevisiae at pH6.25 The initial rates of maltose uptake were measured as $\mathrm{H}^{+}$uptake with a $\mathrm{pH}$ electrode. $\mathrm{KCl}$ was added to the cell suspension to final concentrations of $2.5 \mathrm{mM}$ $(\Delta), 5 \mathrm{~mm}(\square), 7.5 \mathrm{~mm}(O)$ and $10 \mathrm{~mm}(\Delta)$. Control is represented by

Table 2. Effect of some salts on the maltose-transport system in $S$. cerevisiae

$\mathrm{KCl}, \mathrm{KSCN}$ and $\mathrm{NaCl}$ were added to cell suspensions in the concentrations indicated. Initial rates of $\mathrm{H}^{+}$uptake were measured as indicated in the text, after the addition of a pulse of maltose to a final concentration of $50 \mathrm{mM}$.

\begin{tabular}{|c|c|c|}
\hline \multirow{8}{*}{$\begin{array}{l}\mathrm{pH} \\
6.0\end{array}$} & salt & $(\mathrm{mmol} / \mathrm{h}$ per $\mathrm{g})$ \\
\hline & None & 10.0 \\
\hline & $\mathrm{KCl}(10 \mathrm{~mm})$ & 3.1 \\
\hline & $\mathrm{KSCN}(10 \mathrm{mM})$ & 3.0 \\
\hline & $\mathrm{NaCl}(10 \mathrm{mM})$ & 6.1 \\
\hline & $\mathrm{KCl}(200 \mathrm{mM})$ & 0 \\
\hline & $\mathrm{KSCN}(200 \mathrm{mM})$ & 0 \\
\hline & $\mathrm{NaCl}(200 \mathrm{~mm})$ & 2.4 \\
\hline \multirow[t]{7}{*}{4.0} & None & 1.5 \\
\hline & $\mathrm{KCl}(10 \mathrm{mM})$ & 7.5 \\
\hline & $\mathrm{KSCN}(10 \mathrm{~mm})$ & 7.2 \\
\hline & $\mathrm{NaCl}(10 \mathrm{~mm})$ & 8.7 \\
\hline & $\mathrm{KCl}(200 \mathrm{~mm})$ & 5.2 \\
\hline & $\mathrm{KSCN}(200 \mathrm{mM})$ & 5.4 \\
\hline & $\mathrm{NaCl}(200 \mathrm{mM})$ & 8.2 \\
\hline
\end{tabular}

described in the Experimental section with the addition of $\mathrm{KCl}$ to the cell suspension. Fig. 4 summarizes the results obtained for a maltose concentration of $50 \mathrm{~mm}$ : a strong inhibitory effect at $\mathrm{pH} 6$, a slight inhibitory effect at pH4.7 and stimulating effect at $\mathrm{pH} 4.0$. These aspects were studied in more detail at different $\mathrm{pH}$ values, and the Lineweaver-Burk plots of Figs. 5 and 6 illustrate the results. At $\mathrm{pH} 4.5 \mathrm{~K}^{+}$affected only $V_{\text {max. }}$ and transport could be measured for concentrations of $\mathrm{KCl}$ up to $150 \mathrm{~mm}$. At $\mathrm{pH} 6.25$ low concentrations 
of $\mathrm{KCl}$ affected strongly the affinity of the system for maltose : no proton uptake could be detected for $\mathrm{K}^{+}$concentrations above $15 \mathrm{~mm}$. For $\mathrm{pH}$ values in between, both $V_{\text {max. }}$ and $K_{\mathrm{m}}$ were affected (results not shown).

To elucidate how specific was the effect of $\mathrm{K}^{+}$, we measured the rates of uptake of protons in the presence of $\mathrm{KCl}, \mathrm{KSCN}$ and $\mathrm{NaCl}$. Table 2 summarizes the results.

\section{Discussion}

We can conclude from our data that $\mathrm{pH}$ values above 6 have an inhibitory effect on the physiological activity of the yeast by decreasing both $V_{\text {max. }}$ and the apparent affinity of the transport system for maltose (Table 1). This can be explained if we consider transport in terms of an enzymic reaction, catalysed by a permease, with two substrates, maltose and $\mathrm{H}^{+}$. Changes in the concentration of one of the substrates $\left(\mathrm{H}^{+}\right)$will change the apparent kinetic parameters, even at saturating concentration of the other (Dixon \& Webb, 1958).

The effect of $\mathrm{K}^{+}$in this range of $\mathrm{pH}$ goes in the same direction, as if $\mathrm{K}^{+}$were competing with $\mathrm{H}^{+}$, diminishing the degree of protonation of the carrier.

The stimulating effect of $\mathrm{K}^{+}$under acidic conditions (below pH4) solves the apparent contradiction of growth and no transport under these conditions. In culture media, $\mathrm{K}^{+}$is usually present in concentrations at which maltose transport does occur, whereas in our experiments (Table 1 and Fig. 2) $\mathrm{K}^{+}$concentration was very low.

The nature of this $\mathrm{K}^{+}$-stimulating effect needs to be further elucidated. We can speculate that it may be simply a protective effect against excessively acidic extracellular conditions by increasing apparent $\mathrm{pH}$.

The strain that we worked with, under the experimental conditions used, showed similar behaviour in the presence of $\mathrm{KCl}$ and $\mathrm{NaCl}$, although $\mathrm{Na}^{+}$seemed to be less effective than $\mathrm{K}^{+}$ both in the inhibitory effect at pH6 and the stimulating effect at $\mathrm{pH} 4$. On the other hand, the use of a permeant cation $\left(\mathrm{SCN}^{-}\right)$or a nonpermeant one $\left(\mathrm{Cl}^{-}\right)$did not modify the $\mathrm{K}^{+}$effect (see Table 2). These results are in agreement with the mechanism that we postulated above, i.e. a direct effect of $\mathrm{K}^{+}$on the transport system, competing with $\mathrm{H}^{+}$.

Serrano (1977) reported that $\mathrm{KCl}$ inhibited, whereas $\mathrm{NaCl}$ or $\mathrm{KSCN}$ did not affect, maltose transport in $S$. cerevisiae. He used these data to explain the effect of $\mathrm{K}^{+}$on maltose transport as an inhibition of the $\mathrm{K}^{+}$efflux, this being necessary to restore the membrane potential of the cell during the initial $\mathrm{H}^{+}$-maltose uptake. However, he used incubation times of $10-20 \mathrm{~min}$, with the salts in $100 \mathrm{~mm}$-Tris buffer; during this time possible changes induced in extra- and intra-cellular $\mathrm{pH}$ by $\mathrm{SCN}^{-}$and/or Tris may have interfered with his results, in a range of $\mathrm{pH}$ in which the system is highly $\mathrm{pH}$-dependent.

The intracellular $\mathrm{H}^{+}$and $\mathrm{K}^{+}$concentrations seem to be very important in maltose transport. Further experimental work should perhaps be done with plasma-membrane vesicles, as those described by Franzusoff $\&$ Cirillo (1983), in which both the extra- and intra-cellular conditions can be specifically defined, without interference from metabolism.

The results presented here have some important physiological implications. As Serrano (1977) pointed out, the fact that $S$. cerevisiae developed $\mathrm{H}^{+}$symport systems for maltose and other disaccharides may be related to the low affinity of intracellular maltase for maltose $\left(K_{\mathrm{m}} 10 \mathrm{mM}\right)$. The cells must concentrate maltose from the culture medium, maintaining a high intracellular maltose concentration to keep a good rate of maltose hydrolysis. From our experimentally obtained data we can, just by kinetic considerations and assuming the symmetry of the system, explain the buildup of the maltose gradient without any back transport to the extracellular environment. Outside the cell, in a normal medium for growing yeasts, the $\mathrm{pH}$ is about 4 and the concentration of $\mathrm{K}^{+}$is low. Inside the cell, pH will be about 7 (Peña et al., 1982 ) and the concentration of $\mathrm{K}^{+}$about $100 \mathrm{mM}$ (Herbert et al., 1971). Under these conditions $K_{\mathrm{m}}$ inside will be very high and no transport will occur.

These considerations imply that under normal physiological conditions the differences in $\mathrm{pH}$ and $\mathrm{K}^{+}$concentration between the inner face and the outer face of the plasma membrane determine that the $\mathrm{H}^{+}$-maltose symport is unidirectional.

Finally, we may remark that, with the system described above, the yeast can use the $\mathrm{K}^{+}$gradient as a useful energy source for the build-up of a sugar gradient through the plasma membrane, in addition to the protonmotive force.

\section{References}

Brocklehurst, R., Gardner, D. \& Eddy, A. A. (1977) Biochem. J. 162, 591-599

Dixon, M. \& Webb, E. C. (1958) Enzymes, pp. 78-81, Longmans, Green and Co., London

Eddy, A. A. (1982) Adv. Microb. Physiol. 24, 1-79

Eddy, A. A., Philo, R., Earnshaw, P. \& Brocklehurst, R. (1977) FEBS Symp. 42, 250-260

Franzusoff, A. J. \& Cirillo, V. P. (1983) J. Biol. Chem. 258, 3608-3614

Herbert, D., Phipps, P. J. \& Strange, R. E. (1971) Methods Microbiol. 5B, 209-344 
Olivero, I., Ruiz-Macias, C., Chordi, A. \& Peinado, J. M. (1982) Biotechnol. Bioeng. 24, 2725-2729

Peña, P., Barros, F., Gascon, S., Ramos, S. \& Lazo, P. S. (1982) Eur. J. Biochem. 123, 447-453

Seaston, A., Inkson, C. \& Eddy, A. A. (1973) Biochem. J. 134, 1031-1043
Seaston, A., Carr, G. \& Eddy, A. A. (1976) Biochem. J. 154, 669-676

Serrano, R. (1977) Eur. J. Biochem. 80, 97-102

van Uden, N. (1967) Arch. Mikrobiol. 58, 155-166

van Uden, N. (1969) Annu. Rev. Microbiol. 23, 473486 